\title{
Osteochondrosis / Osteoarthrosis and Claw Disorders in Sows, Associated with Leg Weakness
}

\author{
By B. Jørgensen
}

Danish Institute of Agricultural Sciences, Research Centre Foulum, Tjele, Denmark.

\begin{abstract}
Jørgensen B: Osteochondrosis / osteoarthrosis and claw disorders in sows associated with leg weakness. Acta vet. scand. 2000, 41, 123-138. - The objective of this study was to investigate the associations between different leg weakness symptoms and osteochondrosis/osteoarthrosis and claw disorders in sows together with the influence of age on these findings. One hundred and seventeen sows in one herd were followed from 6 months of age until culling and judged for leg weakness once in every gestation using a scale from 1 (normal) to 4 (severe changes). At slaughter changes in joints, growth plates and claws were scored on a scale from 1 (normal) to 5 (very severe changes). Osteoarthrotic changes were strongly associated with osteochondral changes in humeral and femoral condyles. The clinical signs of osteochondrosis and osteoarthrosis were found to be: buck-kneed forelegs, turn out of fore and hind legs, upright pasterns on hind legs, stiff locomotion, lameness and tendency to slip. The clinical signs of claw lesions were found to be: buck-kneed forelegs, upright pasterns, steep hock joints, turn out of hind legs, standing under position on hind legs, stiff movements, swaying hindquarters, goose-stepping hind legs, tendency to slip and lameness. Overgrown claws were strongly associated with leg weakness indicating the need for claw trimming in sow populations.
\end{abstract}

pig; clinical symptoms; locomotory problems; pathology; joint; growth plates; apophysiolysis; dyschondroplasia; degenerative joint disease; toe injury; claw lesions.

\section{Introduction}

In sows, leg weakness is a main reason for lameness which ultimately leads to culling ( $D a$ gorn \& Aumaitre 1979, Penny 1980, D'Allaire et al. 1987, Stein et al. 1990, Cederberg \& Jonsson 1996) and 29\% of Danish dead sows examined post mortem were found to have been euthanized due to leg weakness (Christensen et al. 1995). In the above-mentioned investigations, leg weakness was recorded as a single complex. By subdividing the complex into 14 single traits, Jørgensen (2000) found that some symptoms had greater influence on the longevity of the animal than others.

The most common cause of leg weakness in adolescent pigs is considered to be the sequelae to osteochondrosis in terms of osteochondritis dissecans or secondary degenerative joint disease (osteoarthrosis) (Reiland 1978a, Jubb et al. 1993, Nakano \& Aherne 1993, Jørgensen et al. 1995). Osteochondrosis is a disturbance of endochondral ossification and osteogenesis often leading to osteochondritis dissecans and less frequently to epiphyseolysis (Reiland 1978b). Osteochondritis dissecans in swine is most commonly observed in the medial condyles of the humerus and femur in animals aged 5 to 7 months. Following the loss of the piece of cartilage, the defect is filled by vascular fibrous tissue that eventually is converted to fibrocartilage (Jubb et al. 1985). Osteoarthrosis or ar- 
thropathy develops at a relatively late stage of the disease. The changes consist of irregularities and fibrillation of joint cartilage, ulceration of articular surfaces with formation of fibrocartilaginous or osseous repair tissue, and marginal osteophytes (Reiland 1978a, Jubb et al. 1985).

Claw disorders are probably also a contributory cause of leg weakness and subsequently to culling. Investigations at abattoirs show a high prevalence of claw disorders in sows (Penny et al. 1963, Penny et al. 1965, Brooks et al. 1977, Erdal \& Grøndalen 1986, Simmins \& Brooks 1988, Kornegay et al. 1990, Gjein \& Larssen 1995). However, there is a lack of scientific evidence concerning the relationship between claw disorders and leg weakness, as well as knowledge of the importance of both joint and claw disorders on the prevalence of locomotor problems.

The aim of this study was to characterise the associations between the different leg weakness symptoms and the pathological findings of osteochondrosis/ osteoarthrosis and claw disorders in sows.

\section{Materials and methods}

The data material used in this study has been described previously in Jørgensen (2000) where the results regarding leg weakness and longevity can be found. From a total of 169 culled sows, joints from 117 sows (67 Landrace*Yorkshire crossbreeds and 50 Yorkshire) and claws from 112 sows were collected at slaughter. Joints from one side (in case of lameness, the lame side) and claws from all 4 legs were collected. The feet were removed before scalding. The shoulder, elbow, hip and stifle joints were opened and examined macroscopically for osteochondral and other changes first at the joint surface and then on $1 \mathrm{~cm}$ thick sections cut frontally through the condyles of the distal humerus and femur with a bandsaw. The distal ulna and the ischial tuberosity growth plates were examined by a sagittal section. All changes were scored on a scale from 1 (normal) to 5 (very severe changes/ osteochondritis dissecans) as previously described (Jørgensen et al. 1995). The claw lesions were categorised according to Gjein \& Larssen (1995) with minor modifications. The inner and outer claws of each foot were scored from 1 (normal) to 5 (very severe changes). The following lesions were included: Unequal claw size, overgrown claws (long claws on main and accessory digits with elongated toes), excessive wear on side wall, side wall lesions (cracks), lesions on volar surface (cracks in the harder toe horn, in the white line or in the junction of the heel and toe), overgrown heels (hyperkeratinization on the soft heel tissue), heel lesions (cracks or erosions in the soft heel), and crusts on accessory digits (including torn accessory digits). The evaluation of joint and claw lesions was made by the author without knowledge of the "cohort memberships' or the results of the clinical examinations (Jørgensen 2000).

\section{Statistical methods}

The mutual associations between joint changes as well as the mutual associations between claw lesions were analysed using regression analysis, where the joint or claw traits were analysed one at a time using the other joint or claw traits as explanatory variables (model 1). A normal distribution was assumed. The maximal scores of claw lesions on all 8 claws were used ( 1 recording per animal). A backward elimination procedure was used removing the variables one at a time with the highest $\mathrm{p}$-value until only variables with a p-value below 0.05 were left in the model. There was no breed effect in a preliminary analysis, therefore breed was not included. The procedure PROC REG in SAS was used (SAS Institute Inc. 1989). 
Table 1. Prevalence (\%) and mean score of changes in the joints. No. of sows $=117$

\begin{tabular}{|c|c|c|c|c|c|c|c|}
\hline & \multicolumn{5}{|c|}{ Score $^{\mathrm{a}}$} & \multirow[b]{2}{*}{ Mean } & \multirow[b]{2}{*}{ Code } \\
\hline & 1 & 2 & 3 & 4 & 5 & & \\
\hline \multicolumn{8}{|l|}{ Shoulder } \\
\hline Glenoid cavity & 26 & 35 & 29 & 8 & 2 & 2.3 & Y1 \\
\hline Thin cartilage on humeral head & 5 & 17 & 29 & 25 & 25 & 3.5 & Y2 \\
\hline Flattening of humeral head & 56 & 16 & 21 & 5 & 2 & 1.8 & Y3 \\
\hline \multicolumn{8}{|l|}{ Elbow } \\
\hline \multicolumn{8}{|l|}{ Medial humeral condyle: } \\
\hline Joint surface & 33 & 20 & 20 & 10 & 17 & 2.6 & Y4 \\
\hline Cartilage thickness & 69 & 28 & 2 & 1 & 0 & 1.4 & Y20 \\
\hline Subchondral lesion & 75 & 14 & 5 & 3 & 4 & 1.5 & Y21 \\
\hline Surface tears & 77 & $23^{b}$ & - & - & - & - & Y30 \\
\hline \multicolumn{8}{|l|}{ Lateral humeral condyle: } \\
\hline Joint surface & 52 & 26 & 13 & 2 & 7 & 1.9 & Y5 \\
\hline Subchondral lesion & 96 & 3 & 0 & 0 & 1 & 1.1 & Y23 \\
\hline Surface tears & 87 & $13^{\mathrm{b}}$ & - & - & - & - & Y31 \\
\hline Sagittal central groove & 66 & 26 & 4 & 2 & 2 & 1.5 & Y6 \\
\hline \multicolumn{8}{|l|}{ Anconeal process: } \\
\hline Joint surface & 47 & 18 & 13 & 7 & 15 & 2.3 & Y7 \\
\hline Osteophytes & 86 & $14^{\mathrm{b}}$ & - & - & - & - & Y33 \\
\hline \multicolumn{8}{|l|}{ Proximal edge of radius: } \\
\hline Osteophytes & 80 & $20^{\mathrm{b}}$ & - & - & - & - & Y34 \\
\hline Synovial fossa of radius & 76 & 15 & 6 & 2 & 1 & 1.4 & Y9 \\
\hline Synovial fossa of ulna & 63 & 16 & 11 & 5 & 5 & 1.7 & Y10 \\
\hline Surface tears on radius and ulna & 89 & $11^{\mathrm{b}}$ & - & - & - & - & Y32 \\
\hline \multicolumn{8}{|l|}{ Distal ulna growth plate } \\
\hline Lesion & 79 & 9 & 10 & 2 & 0 & 1.4 & Y24 \\
\hline \multicolumn{8}{|l|}{ Hip } \\
\hline Thin cartilage on femoral head & 40 & 18 & 27 & 9 & 5 & 2.2 & Y11 \\
\hline Flattening of femoral head & 90 & 6 & 4 & 0 & 0 & 1.2 & Y12 \\
\hline \multicolumn{8}{|l|}{ Stifle } \\
\hline \multicolumn{8}{|l|}{ Medial femoral condyle: } \\
\hline Joint surface & 57 & 16 & 13 & 5 & 10 & 2.0 & Y13 \\
\hline Transverse clefts in cartilage & 28 & 27 & 26 & 13 & 7 & 2.5 & Y14 \\
\hline Cartilage thickness & 9 & 27 & 50 & 11 & 3 & 2.7 & Y25 \\
\hline Subchondral lesion & 87 & 7 & 5 & 0 & 2 & 1.2 & Y26 \\
\hline \multicolumn{8}{|l|}{ Lateral femoral condyle: } \\
\hline Joint surface & 90 & 8 & 1 & 1 & 1 & 1.2 & Y15 \\
\hline Transverse clefts in cartilage & 89 & 10 & 1 & 0 & 0 & 1.1 & Y16 \\
\hline Cartilage thickness & 61 & 28 & 11 & 0 & 0 & 1.5 & Y27 \\
\hline Subchondral lesion & 97 & 2 & 1 & 0 & 0 & 1.0 & Y28 \\
\hline Widening of intercondyloid fossa & 33 & 42 & 20 & 3 & 3 & 2.0 & Y17 \\
\hline Flattening of patellar groove & 60 & 21 & 12 & 4 & 3 & 1.7 & Y18 \\
\hline Widening of intratrochanteric fossa & 52 & 26 & 13 & 5 & 4 & 1.8 & Y19 \\
\hline \multicolumn{8}{|l|}{ Ischial tuberosity growth plate } \\
\hline Lesion & 67 & 16 & 12 & 2 & 4 & 1.6 & Y29 \\
\hline
\end{tabular}

a Score 1 (normal) to 5 (very severe changes/osteochondritis dissecans).

${ }^{\mathrm{b}}$ Score 1 (normal) to 2 (non-normal). 
The effects of location of the claw lesion were analysed by repeated measurement analysis using the following model:

$\mathrm{Y}_{\mathrm{ijklm}}=\mu+\mathrm{a}_{\mathrm{i}}+\mathrm{b}_{\mathrm{j}}+\mathrm{ab}_{\mathrm{ij}}+\mathrm{d}_{\mathrm{k}}+\mathrm{S}_{\mathrm{kl}}+\mathrm{e}_{\mathrm{ijk} \mathrm{k}}$ (model 2)

where $Y_{i j k l m}$ is the $m^{\text {th }}$ observation of claw lesion for the $\mathrm{l}^{\text {th }}$ sow on the $\mathrm{i}^{\text {th }}$ foot on the $\mathrm{j}^{\text {th }}$ location belonging to the $\mathrm{k}^{\text {th }}$ breed; $\mu$ is the mean; $\mathrm{a}_{\mathrm{i}}$ is the fixed effect of foot ( $\mathrm{i}$ is fore or hind foot); $b_{j}$ is the fixed effect of location ( $j$ is lateral or medial); $a b_{i j}$ is the interaction term between foot and location; $d_{k}$ is the fixed effect of breed ( $k$ is crossbreed (LY or YL) or Yorkshire); $\mathrm{S}_{\mathrm{kl}}$ is the random effect of sow within breed; and $\mathrm{e}_{\mathrm{ijklm}}$ is the random residuals. Preliminary analysis showed no differences between left and right side, therefore 'side' was excluded from the model. The procedure PROC MIXED in SAS was used (SAS Institute Inc. 1992).

The associations between joint changes, claw lesions and leg weakness were analysed using regression analysis, where the leg weakness traits were analysed one at a time using the joint and claw traits as explanatory variables. The analyses were subdivided into 3 groups: one analysing the associations between the traits on fore legs, one the associations between the traits on hindlegs and one the associations between the locomotory traits and the pathological traits on all legs. The maximal scores of leg weakness over time for each sow (Jørgensen 2000) and the maximal scores of claw disorders over 4 (in the analyses of fore or hind legs) or 8 claws were used (model 3). Similar analyses were executed regarding the associations between the last clinical investigation (Jørgensen 2000) and the pathological findings at slaughter (model 4). A backward elimination procedure was used by removing the variables one at a time with the highest $\mathrm{p}$-value until only variables with a $\mathrm{p}$ value below 0.05 were left in the model. The procedure PROC REG in SAS was used ( $S A S$ Institute Inc. 1989).

\section{Results \\ Joint changes}

The age distribution of the 117 sows was: $<1$ year: 3 sows; $1-2$ years: 20 sows; $2-3$ years: 28 sows; 3-4 years: 57 sows; $4-5$ years: 9 sows. The prevalence and mean scores of the joint changes are shown in Table 1. All scores greater than 1 represented a deviation from 'normal'. The changes on the joint surface of the humeral condyles, the anconeal process, and the femoral condyles were frequently osteoarthrotic rather than osteochondrotic, consisting of ulceration with formation of fibrocartilaginous or osseous repair tissue. $27.8 \%$ of the sows had had osteochondritis dissecans (score 5) in the elbow joint, of these $20.0 \%$ were found in one or both humeral condyles and $15.0 \%$ on the anconeal process. Further, $10.3 \%$ of the sows had had osteochondritis dissecans in the femoral condyles. Four sows had total, and 2 partial, epiphysial separation (scores 5 and 4, respectively), one sow had had ischial tuberosity separation twice followed by reunion. Degeneration and erosion of joint cartilage were often found in the form of transverse clefts in the cartilage of the femoral condyles and surface tears (wear lines) on the humeral condyles and on the proximal radius and ulna. Marginal osteophytes were discovered on the proximal edge of radius and on the anconeal process, i.e. exclusively in the elbow joint. Besides the above-mentioned changes, 3 cases of bone fractures and 3 cases of separation (apophysiolysis) of the anconeal processes were found.

For the analyses of associations between leg weakness and joint changes, new variables combining the scores of the changes in the medial and lateral condyles were created as the maximal score of the 2 condyles in the distal humerus and femur and osteophyte changes on 
Table 2. New variables created by combining the scores of the changes in the medial and lateral condyles in the distal humerus and femur and osteophyte changes on anconeal process and proximal edge of radius.

\begin{tabular}{|c|c|c|}
\hline Code & Code & Mean score \\
\hline \multicolumn{3}{|l|}{ Humeral condyles: } \\
\hline IELBOW joint surface score & $\max (\mathrm{Y} 4, \mathrm{Y} 5)$ & 2.88 \\
\hline TELBOW cartilage thickness score & Y20 & 1.32 \\
\hline LELBOW subchondral lesion score & $\max (\mathrm{Y} 21, \mathrm{Y} 23)$ & 1.44 \\
\hline SURFTEAR surface tears score & $\max (\mathrm{Y} 30, \mathrm{Y} 31, \mathrm{Y} 32)$ & $1.28^{\mathrm{a}}$ \\
\hline OSTEOPH osteophytes score & $\max (\mathrm{Y} 33, \mathrm{Y} 34)$ & $1.27^{\mathrm{a}}$ \\
\hline \multicolumn{3}{|l|}{ Femoral condyles: } \\
\hline ISTIFLE joint surface score & $\max (\mathrm{Y} 13, \mathrm{Y} 15)$ & 2.03 \\
\hline transverse clefts score & $\max (\mathrm{Y} 14, \mathrm{Y} 16)$ & 2.47 \\
\hline cartilage thickness score & $\max (Y 25, Y 27)$ & 2.71 \\
\hline subchondral lesion score & $\max (Y 26, Y 28)$ & 1.26 \\
\hline
\end{tabular}

${ }^{a}$ Scoring 1 (normal) to 2 (non-normal)

b Codes from Table 1 .

anconeal process and proximal edge of radius (Table 2).

Significant differences between breeds were found for some of the traits in Tables 1 and 2 $\left(\chi^{2}\right.$-test): Yorkshire sows had higher scores for glenoid cavity $(\mathrm{p}<0.01)$, joint surface on humeral condyles $(\mathrm{p}<0.06)$, osteophyte formation in elbow joint $(p<0.01)$, and thinning of cartilage on femoral head $(\mathrm{p}<0.05)$, while crossbreeds had higher scores for transverse clefts in femoral condyles $(\mathrm{p}<0.01)$.

Analyses of interrelations between joint changes using model 1 showed some interesting associations (Table 3):

- Osteophyte formation and subchondral lesions in humeral condyles (strongly significant).

- Osteophyte formation and surface tears in the elbow joint.

- Joint surface changes on humeral condyles and sagittal central groove.

- Joint surface changes on humeral condyles and synovial fossa of radius.

- Anconeal process lesions and synovial fossa of radius (strongly significant).
- Osteochondral lesions in the distal ulna growth plate were associated with joint surface changes and subchondral lesions in the femoral condyles.

- Transverse clefts in cartilage and thickening of cartilage in femoral condyles (strongly significant).

- Osteochondral lesions in the ischial tuberosity growth plate were not positively associated with other changes.

\section{Claw lesions}

The prevalence of claw lesions and leastsquares means from the analyses of the distribution of claw lesions by foot (fore/ hind) and location (lateral/medial) using model 2 are shown in Table 4. Preliminary analysis showed no differences between the left and right side, i.e. the changes could be regarded as symmetrical, therefore combined values (the maximal scores of the claws on the left and right side) are shown in Table 4. Interaction terms were significant for nearly all the traits, therefore no general conclusions with regard to differences between feet and locations (main effects) could 


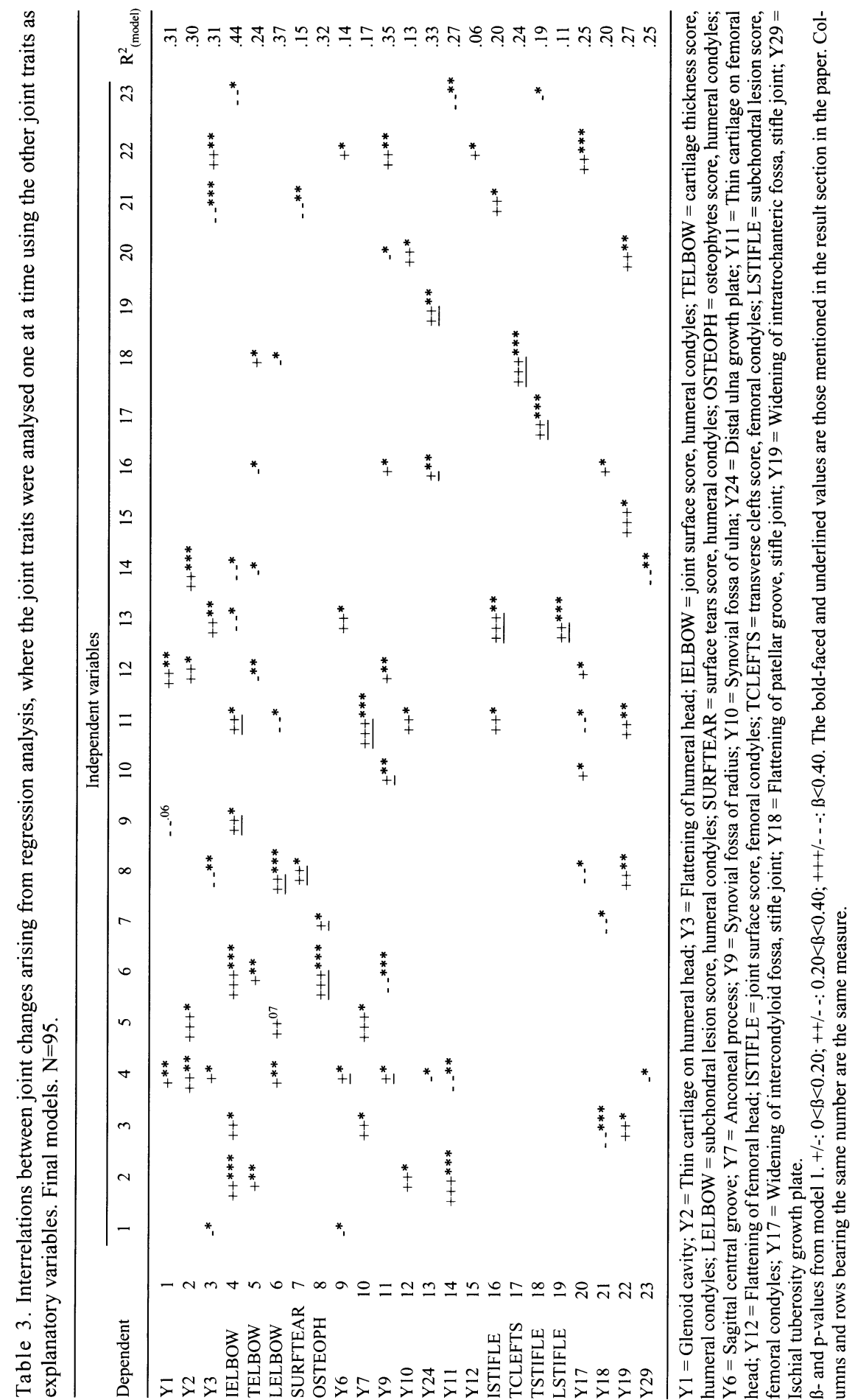


Table 4. Prevalence $(\%)$ and least-squares means of claw lesions. No. of sows $=112$

\begin{tabular}{|c|c|c|c|c|c|c|c|}
\hline & & \multicolumn{5}{|c|}{ Score $^{y}$} & \multirow{2}{*}{ LSMeans $^{\mathrm{z}}$} \\
\hline & & 1 & 2 & 3 & 4 & 5 & \\
\hline \multicolumn{8}{|c|}{ Unequal claw size } \\
\hline Fore & & 49 & 40 & 12 & 0 & 0 & $1.6^{\mathrm{a}}$ \\
\hline Hind & & 3 & 30 & 40 & 25 & 2 & $2.7^{\mathrm{b}}$ \\
\hline \multicolumn{8}{|c|}{ Overgrown claws } \\
\hline \multirow[t]{2}{*}{ Fore } & Lateral & 88 & 10 & 2 & 0 & 0 & $1.1^{\mathrm{a}}$ \\
\hline & Medial & 83 & 12 & 5 & 0 & 0 & $1.2^{\mathrm{a}}$ \\
\hline \multirow[t]{2}{*}{ Hind } & Lateral & 44 & 38 & 16 & 1 & 1 & $1.8^{\mathrm{b}}$ \\
\hline & Medial & 44 & 24 & 21 & 8 & 4 & $2.0^{\mathrm{c}}$ \\
\hline \multicolumn{8}{|c|}{ Overgrown claws on accessory digits } \\
\hline \multirow[t]{2}{*}{ Fore } & Lateral & 24 & 32 & 26 & 17 & 1 & $2.4^{\mathrm{ac}}$ \\
\hline & Medial & 42 & 20 & 18 & 18 & 2 & $2.2^{\mathrm{a}}$ \\
\hline \multirow[t]{2}{*}{ Hind } & Lateral & 46 & 25 & 18 & 6 & 6 & $2.0^{\mathrm{b}}$ \\
\hline & Medial & 22 & 25 & 30 & 16 & 6 & $2.6^{\mathrm{c}}$ \\
\hline \multicolumn{8}{|c|}{ Excessive wear on side wall } \\
\hline \multirow[t]{2}{*}{ Fore } & Lateral & 65 & 29 & 6 & 0 & 0 & $1.4^{\mathrm{a}}$ \\
\hline & Medial & 69 & 28 & 3 & 1 & 0 & $1.4^{\mathrm{a}}$ \\
\hline \multirow[t]{2}{*}{ Hind } & Lateral & 44 & 26 & 30 & 0 & 0 & $1.9^{\mathrm{b}}$ \\
\hline & Medial & 25 & 30 & 38 & 6 & 1 & $2.3^{\mathrm{c}}$ \\
\hline \multicolumn{8}{|c|}{ Side wall lesions } \\
\hline \multirow[t]{2}{*}{ Fore } & Lateral & 71 & 10 & 10 & 6 & 3 & $1.6^{\mathrm{a}}$ \\
\hline & Medial & 81 & 9 & 6 & 4 & 0 & $1.3^{\mathrm{b}}$ \\
\hline \multirow[t]{2}{*}{ Hind } & Lateral & 50 & 12 & 16 & 13 & 9 & $2.2^{\mathrm{c}}$ \\
\hline & Medial & 86 & 5 & 8 & 1 & 0 & $1.2^{\mathrm{b}}$ \\
\hline \multicolumn{8}{|c|}{ Lesions on volar surface } \\
\hline \multirow[t]{2}{*}{ Fore } & Lateral & 54 & 15 & 18 & 10 & 4 & $1.9^{\mathrm{a}}$ \\
\hline & Medial & 73 & 16 & 8 & 2 & 1 & $1.4^{\mathrm{b}}$ \\
\hline \multirow[t]{2}{*}{ Hind } & Lateral & 44 & 13 & 17 & 13 & 14 & $2.4^{\mathrm{c}}$ \\
\hline & Medial & 96 & 2 & 3 & 0 & 0 & $1.1^{\mathrm{d}}$ \\
\hline \multicolumn{8}{|c|}{ Overgrown heels } \\
\hline \multirow[t]{2}{*}{ Fore } & Lateral & 60 & 23 & 13 & 3 & 2 & $1.6^{\mathrm{a}}$ \\
\hline & Medial & 84 & 10 & 5 & 0 & 1 & $1.3^{\mathrm{b}}$ \\
\hline \multirow[t]{2}{*}{ Hind } & Lateral & 15 & 15 & 35 & 17 & 18 & $3.1^{\mathrm{c}}$ \\
\hline & Medial & 96 & 4 & 0 & 0 & 1 & $1.1^{b}$ \\
\hline \multicolumn{8}{|c|}{ Heel lesions } \\
\hline \multirow[t]{2}{*}{ Fore } & Lateral & 94 & 3 & 3 & 1 & 0 & $1.1^{\mathrm{a}}$ \\
\hline & Medial & 94 & 2 & 3 & 2 & 0 & $1.1^{\mathrm{a}}$ \\
\hline Hind & Lateral & 71 & 7 & 13 & 5 & 4 & $1.7^{\mathrm{b}}$ \\
\hline & Medial & 99 & 1 & 0 & 0 & 0 & $1.0^{\mathrm{a}}$ \\
\hline Crusts at & torn claw. & digi & & & & & \\
\hline Fore & Lateral & 90 & 2 & 4 & 3 & 2 & $1.2^{\mathrm{ac}}$ \\
\hline & Medial & 93 & 2 & 5 & 1 & 0 & $1.1^{\mathrm{a}}$ \\
\hline Hind & Lateral & 81 & 1 & 2 & 6 & 10 & $1.6^{\mathrm{b}}$ \\
\hline & Medial & 87 & 7 & 2 & 5 & 0 & $1.4^{\mathrm{c}}$ \\
\hline
\end{tabular}

${ }^{\mathrm{x}}$ Maximal scores of the claw lesions on the left and right side. ${ }^{\mathrm{y}} \mathrm{Score} 1$ (normal) to 5 (very severe changes)

${ }^{\mathrm{z}}$ Least-squares means from model $2,{ }^{\mathrm{a}, \mathrm{b}, \mathrm{c}, \mathrm{d}}$ : figures with different letters are significantly different at $\mathrm{p}<=0.05$ 
Table 5. Interrelations between claw lesions arising from regression analysis, where the claw traits were analysed one at a time using the other claw traits as explanatory variables. Final models. $\mathrm{N}=107$.

\begin{tabular}{|c|c|c|c|c|c|c|c|c|c|c|c|}
\hline \multirow[b]{2}{*}{ Dependent } & & \multicolumn{9}{|c|}{ Independent variables } & \multirow[b]{2}{*}{$\mathrm{R}_{\text {(model) }}^{2}$} \\
\hline & & 1 & 2 & 3 & 4 & 5 & 6 & 7 & 8 & 9 & \\
\hline Unequal claw size ${ }^{\mathrm{a}}$ & 1 & & $+++* * *$ & & & & & $+^{*}$ & & & .37 \\
\hline Overgrown claws & 2 & $+++* * *$ & & & & & & $-* *$ & & & .42 \\
\hline Overgrown claws on acc. digits & 3 & & $++* *$ & & & & & & & $+*$ & .19 \\
\hline Excessive wear on side wall & 4 & & & & & $-*$ & & & & & .18 \\
\hline Side wall lesions & 5 & & & & - . - * & & $++* *$ & $++*$ & & & .22 \\
\hline Lesions on volar surface & 6 & & & & & $++* *$ & & +.08 & & & .15 \\
\hline Overgrown heels & 7 & $++*$ & $--* *$ & & & $++* *$ & $+^{*}$ & & $--* *$ & & .29 \\
\hline Heel lesions & 8 & & & & & & & $--*$ & & & .05 \\
\hline Crusts and torn claws on acc. digits & 9 & & & $++*$ & & & & & - -* & & .08 \\
\hline
\end{tabular}

a Maximal scores of claw lesions on all 8 claws

$B$ and p-values from model 1

be drawn. The most prevalent and most severe changes were: Overgrown heels and lesions on volar surface; Unequal claw size was most prevalent on hind legs; Overgrown claws, overgrown claws on accessory digits and excessive wear on side wall were most prevalent on the medial hind claws while the rest of the variables were most prevalent on the lateral hind claws. The medial hind claws had hardly any lesions on the volar surface and heels (overgrown heels and heel lesions). Of the fore claws the lateral developed more changes than the medial regarding side wall lesions, lesions on volar surface and overgrown heels. In $21 \%$ of the sows, cracks between the side wall and the volar surface were seen on lateral hind claws (corresponding figures for the other claws: $9 \%$ on lateral fore claws, $3 \%$ on medial fore claws and $1 \%$ on medial hind claws). Often these cracks were in the white line in the posterior abaxial part of the claw. Further, cracks between toe and heel were often seen. Differences between breed were only significant for one trait (overgrown claws on accessory digits) in favour of Yorkshire $(\mathrm{p}<0.05)$.

Analysing interrelations between claw lesions using model 1 showed that several claw lesions were associated (Table 5). Among others was unequal claw size strongly associated with overgrown claws and less strongly with overgrown heels.

Influence of joint changes and claw lesions on leg weakness

In Tables 6 and 7, the results of the analyses of the influence of joint changes and claw lesions on leg weakness analysed as the maximal score over time for each sow (model 3, Table 6) and the last clinical investigation before culling (model 4, Table 7), respectively, are shown. The clinical signs of osteochondrosis and osteoarthrosis were found to be: buck-kneed forelegs, fore and hind legs turned out, upright pasterns on hind legs, stiff locomotion in front and rear, lameness/sore-leggedness and tendency to slip (for lesions in the ischial tuberosity growth plate only). Some traits were negatively associated with osteochondrosis/osteoarthrosis, these were: weak pasterns and splayed digits on forelegs and brisk movement. The clinical signs of claw lesions were found to be: standing under position on hind legs, upright pasterns on hind legs, steep hock joints, hind legs turned out, stiff movement in front, swaying hindquar- 


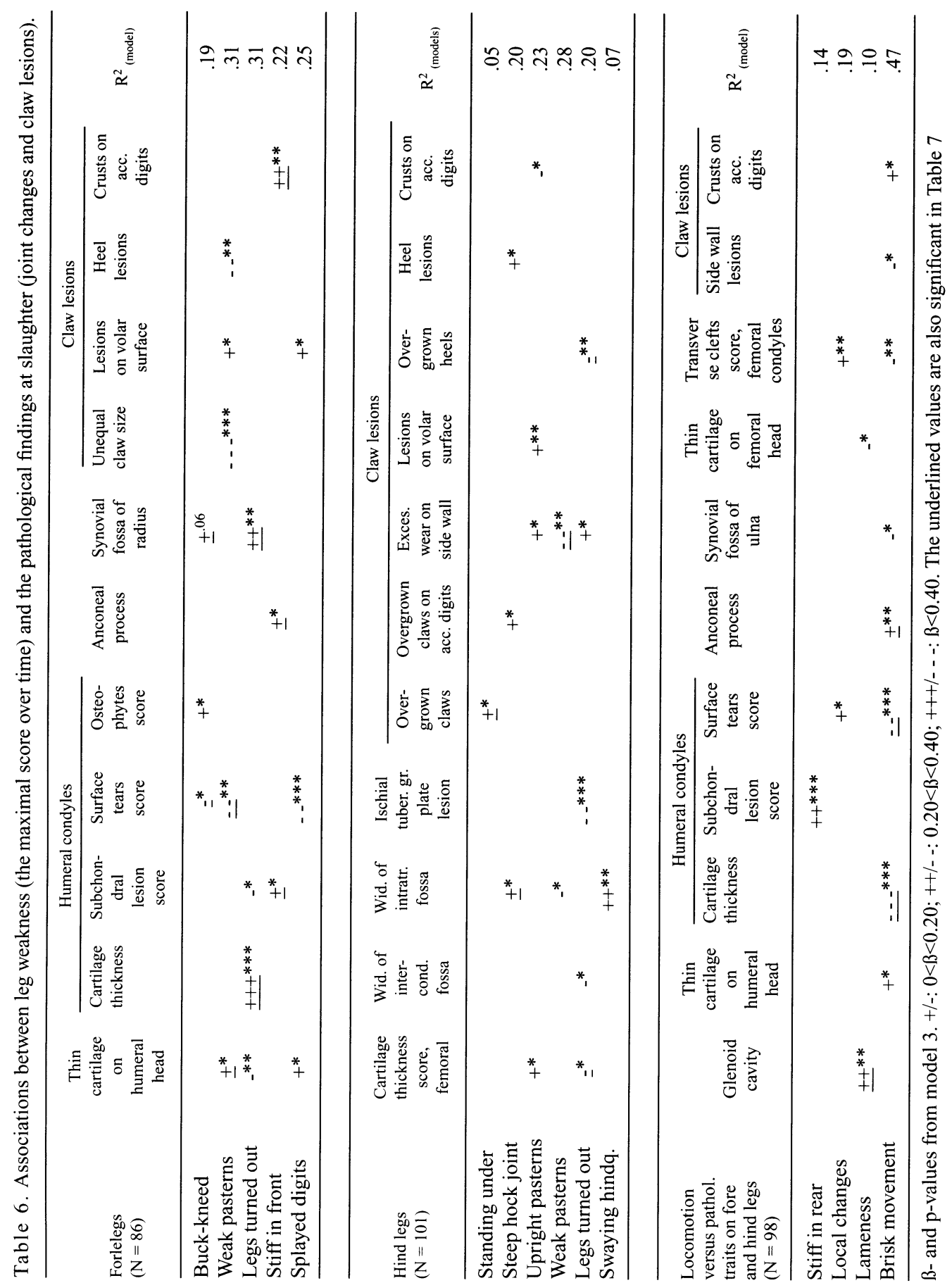




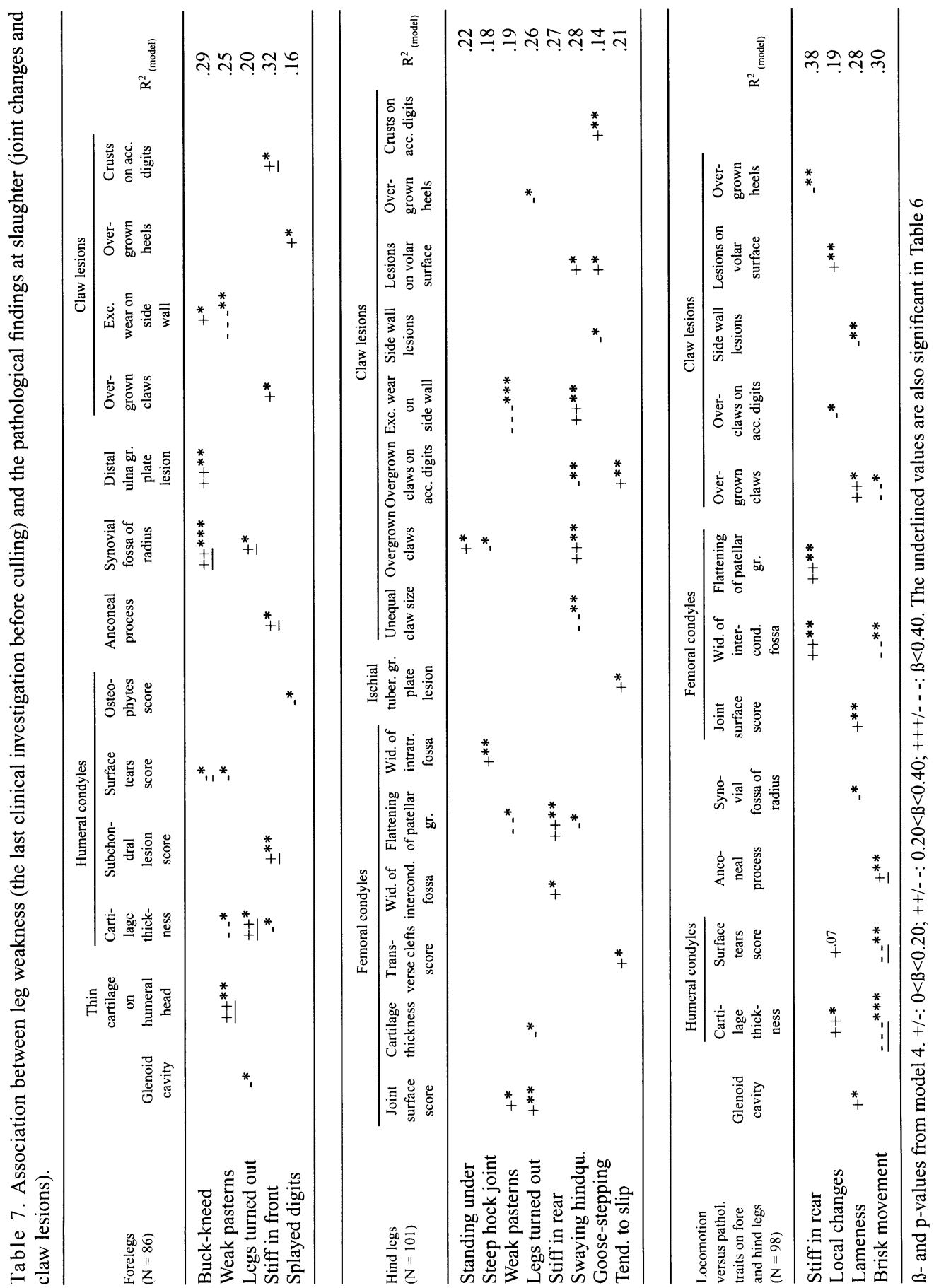


ters, goose-stepping hind legs, tendency to slip and lameness, whereas weak pasterns on fore and hind legs and brisk movement were negatively associated with some claw lesions.

\section{Discussion}

Joint changes

Osteochondrosis is frequently stated to be a generalized condition with bilateral symmetry (Grøndalen 1974a, Olsson \& Reiland 1978, Reiland 1978b), which is the reason why only one side of the pigs was examined in this study. The prevalence and severity of joint changes in the sows in this study differed from what is reported in younger animals slaughtered at about $95 \mathrm{~kg}$ (Jørgensen et al. 1995). The ranking of the locations was the same for the 2 age groups and corresponds to findings of Häni et al. (1983) which confirms the hypothesis that the elbow joints might be more sensitive towards trauma and overloading resulting in a dissecting lesion (osteochondritis dissecance) than the stifle joints (Jørgensen et al. 1995). Furthermore, the sows had osteoarthrotic changes in the form of degeneration and erosion of joint cartilage, surface tears (wear lines) on humeral condyles and proximal radius and ulna and transverse clefts on the femoral condyles, marginal osteophytes in elbow joints, flattening of the joint surface and exposure of the underlying bone on the humeral and femoral heads, that was not seen in slaughter pigs, in accordance with findings of Grøndalen (1974b), Reiland (1978b) and Nakano \& Aherne (1993).

Surprisingly, lesions in the ischial tuberosity growth plate were more prevalent $(33 \%)$ than lesions in the distal ulna growth plate $(21 \%)$, which is stated to be one of the predilection sites for osteochondrosis (Grøndalen 1974a, Reiland 1978b, Nakano et al. 1981, Nakano et al. 1987). Apophysiolysis tuber ischii was found in $5 \%$ of the sows, either total or partial, but as only one side of the carcasses was inves- tigated in this study, it is not known whether the condition was uni- or bilateral. Petterson \& Reiland (1967) reported the prevalence of apophysiolysis tuber ischii to be $5 \%$ (218 out of 4101 ) in a study of sows sent to emergency slaughter, of these $88 \%$ were bilateral. They found the detached tuberosity to reunite to the ischium in rare occasions, which was also found in one sow in the present investigation. Synovial fossa changes were mainly of an osteoarthrotic nature and were found to be associated with joint surface changes on humeral condyles and anconeal process (Table 3 ) as well as some leg weakness symptoms (Tables 6 and 7). In accordance with findings by Petterson and Reiland (1967), lesions in the ischial tuberosity growth plate were not associated with other joint changes in this investigation. Transverse clefts in cartilage was strongly associated with thickening of cartilage in femoral condyles, and marginal osteophyte formation was strongly associated with subchondral lesions and surface tears in the elbow joint, indicating that these osteoarthrotic changes are consequences of osteochondrosis.

\section{Claw lesions}

The lateral hind claws were the most frequent location for lesions in the form of side wall and volar surface lesions, overgrown heels and heel lesions (Table 4) which is in accordance with findings by Penny et al. (1963, 1965), Fritschen et al. (1976), Brooks et al. (1977), Arthur et al. (1983), Webb et al. (1984), Simmins \& Brooks (1988), Kornegay et al. (1990), Raundahl (1992), Gjein \& Larssen (1995) and Mouttotou et al. (1997). The difference in prevalence and severity of the lesions on fore and hind claws in tied sows may be explained by a bad floor hygiene for the hind claws which, in particular, predisposes to heel lesions Smedegaard (1975) and overgrown heels Gjein \& Larssen (1995). Overgrown claws were most severe on 
the medial hind claw, which could be a result of the lower weight bearing (Webb 1984) and consequently less wear on the claw especially in the case of uneven claw size (Table 5). Overgrown claws were often seen in boars and sows housed in stalls and described as a result of limited exercise Von Knezevic (1962). In agreement with findings of Brooks et al. (1977), Simmins \& Brooks (1988), Gjein \& Larssen (1995) and Mouttotou et al. (1997), several claw lesions were found to be associated (Table 5), e.g. lesions in the side wall and on the volar surface and overgrown heels.

Influence of joint changes and claw lesions on leg weakness

In Tables 6 and 7, the results of the analyses of the associations between leg weakness subdivided into single traits and the pathological findings at slaughter (joint changes and claw lesions) are shown. Table 6 shows the results of the associations between the maximal score over time for each sow and the pathological findings, while Table 7 shows the associations between the last clinical investigation before culling and these findings. A positive association in Table 7 indicates a direct simultaneous effect of the lesions on the clinical appearance eventually leading to culling, whereas an association between the maximal scores and the pathological changes (Table 6) shows whether the pathological changes had caused pain and thus clinical symptoms at a previous time not necessary leading to culling. Some lesions could have healed up without scars or secondary changes in which case no associations could be found. The $\mathrm{R}^{2}$ values of the models are not very high in these analyses indicating that other circumstances /conditions are of importance for leg weakness than the pathological findings of the joints and claws at the time of slaughter.

The clinical signs of osteochondrosis have been described to include buck-kneed forelegs, upright and weak pasterns, standing under position on fore and hind legs, swaying hindquarters and lameness (Nielsen 1973) and a shortened stride, stiffness, angular limb deformities and lameness (Hill 1998). Hill (1990) found that pigs suffering from upright pasterns were more sensitive with regard to joint lesions. In this study weak pasterns and splayed digits on forelegs were negatively associated with osteochondrosis/ osteoarthrosis. It is interesting that not only osteochondritis dissecance but also thick cartilage and osteochondral lesions in condyles and growth plates were associated with leg weakness in the sows in this study, in contrast to findings in young animals of $95 \mathrm{~kg}$ (Jørgensen et al. 1995) in which osteochondritis dissecance, but not osteochondral (subchondral) lesions linearly scored, was associated with legs turned out and stiff movement. Results by Grøndalen (1974c), Reiland et al. (1980), Goedegebuure et al. (1988) and Jørgensen (1995) showed no significant association between osteochondrosis and leg weakness in slaughter pigs.

Associations between distal ulna growth plate lesions and buck-kneed fore legs and between the lesions in the ischial tuberosity growth plate and tendency to slip were found in this study. Verdijk (1969) found a positive correlation between leg weakness and lesions in the distal ulna growth plate and Reiland (1978b) stated that lesions in the distal ulna growth plate could cause retardation of the ulnar growth leading to bowed legs. Goose-stepping hind legs and tendency to slip are described as symptoms of the ischial tuberosity apophysiolysis (Sabec 1971, Done et al. 1979, Van Alstine \& Toben 1989) in unilateral cases, whereas bilateral detachment results in a dog-sitting position (Done et al. 1979, Van Alstine \& Toben 1989).

Some joint changes are described as synovial fossae and regarded as normal features of 
Doige \& Horowitz (1975). This applies to the changes in the glenoid cavity, the thinning of cartilage on the cranial portion of the humeral head, the sagittal central groove on distal humerus and synovial fossa of proximal radius and ulna. In this investigation, the changes in the glenoid cavity were associated with lameness. The thinning of cartilage on the humeral head was associated with weak pasterns, splayed digits on forelegs and brisk movement which again were negatively associated with osteochondrosis and leg weakness. Synovial fossa of radius was associated with buck-kneed forelegs and forelegs turned out and was also associated with joint surface changes in the humeral condyles and changes in the anconeal process (Table 3). The results of this study thus confirm the statements of Doige \& Horowitz (1975) with regard to the thinning of cartilage on the humeral head. However, the present study found that the changes in the glenoid cavity, the synovial fossae of radius and the sagittal central groove on distal humerus are of importance to the leg weakness/ osteochondrosis complexes and therefore abnormal features. Deformations in the stifle joint seem to be of importance to the clinical leg problems. These changes are described by Nielsen (1973) and Reiland (1978b) as part of the osteochondral syndrome. Flattening of humeral and femoral heads was of no clinical importance for the animal.

Claw lesions and in particular overgrown claws seem to give rise to serious problems with regard to leg weakness, i.e. lameness, stiff in front, standing under position on hind legs and swaying hindquarters. Also, Smedegaard (1987) stated that the symptoms of overgrown claws were: lameness, short steps, stiff movement and swaying hindquarters. In order to improve leg soundness in sows, claw trimming may therefore be a possibility. Unequal claw size had no effect on leg weakness which is in agreement with findings of Calabotta et al. (1982) and Arthur et al. (1983).

The symptoms were in many cases the same for osteochondrosis /osteoarthrosis and claw lesions, which makes it difficult to differentiate between the 2 complexes from the clinic point of view. For both osteochondrosis /osteoarthrosis and claw lesions, it was seen that weak pasterns were found significantly more in animals not suffering from these lesions. This corresponds to reports of Grøndalen (1974c) who stated that pigs having weak pasterns on front legs achieved the best gait score and Jørgensen (1995) who found that weak pasterns on forelegs were not associated with the other leg weakness symptoms, indicating that they are perhaps not part of the leg weakness syndrome. By combining the results from Tables 6 and 7 with the results from Tables 3 and 7 in Jørgensen (2000), the following results were found with regard to the significance of the different leg weakness symptoms as indicator traits of joint and claw disorders, locomotory problems and decreased longevity: claws uneven on fore and hind legs and bursitis carpalis and tarsalis were of no importance with regard to locomotory problems, longevity and joint lesions; weak pasterns on fore and hind legs and splayed digits on forelegs were favourable traits; while the rest of the symptoms described in Jørgensen (2000) were unfavourable traits for the animals.

It is concluded that:

- osteoarthrotic changes were strongly associated with osteochondral changes in humeral and femoral condyles.

- the clinical signs of osteochondrosis and osteoarthrosis were found to be: buck-kneed forelegs, fore and hind legs turned out, upright pasterns on hind legs, stiff locomotion, lameness and tendency to slip (for lesions in the ischial tuberosity growth plate only).

- the clinical signs of claw lesions were found 
to be: buck-kneed forelegs, upright pasterns, steep hock joints, hind legs turned out, standing under position on hind legs, stiff movements, swaying hindquarters, goose-stepping hind legs, tendency to slip and lameness.

- overgrown claws was of great importance with regard to leg weakness indicating the need for claw trimming in sows.

\section{Acknowledgements}

This investigation was carried out in the research herd 'Grønhøj' owned by the Federation of Danish Pig Producers and Slaughterhouses. The staff of this herd and the staff on Jutland's Slaughterhouse in Morsø were very helpful during the practical part of the investigation. I. R. Korsgaard gave helpful comments regarding the statistics and N. Friggens provided valuable comments on the manuscript. They are all gratefully acknowledged for their assistance. The investigation was supported by the Federation of Danish Pig Producers and Slaughterhouses.

\section{References}

Arthur SR, Kornegay ET, Thomas HR, Veit HP, Notter $D R$, Barczewski RA: Restricted energy intake and elevated calcium and phosphorus intake during growth. III. Characterization of feet and limbs and soundness scores of sows during three parities. J.Anim.Sci. 1983, 56, 876-886.

Brooks PH, Smith DA, Irwin VCR: Biotinsupplementation of diets; the incidence of foot lesions, and the reproductive performance of sows. Vet.Rec. 1977, 101, 46-50.

Calabotta DF, Kornegay ET, Thomas HR, Knight JW, Notter DR, Veit HP: Restricted energy intake and elevated calcium and phosphorus intake for gilts during growth. I. Feedlot performance and foot and leg measurements and scores during growth. J.Anim.Sci. 1982, 54, 565-575.

Cederberg ER, Jonsson L: Sow culling in Sweden. Proceedings of NJF-seminar no.265 "Longevity of Sows". Research Centre Foulum, Denmark, 27.-28. March 1996, 7-8.

Christensen G, Vraa-Andersen L, Mousing J: Causes of mortality among sows in Danish pig herds. Vet.Rec. 1995, 137, 396-399.

D'Allaire S, Stein TE, Leman AD: Culling patterns in selected Minnesota swine breeding herds. Can.J.Vet.Res. 1987, 51, 506-512.

Dagorn J, Aumaitre A: Sow culling: reasons for and effect on productivity. Livest.Prod.Sci. 1979, 6, 167-177.

Doige C, Horowitz A: A study of articular surfaces and synovial fossae of the pectoral limb of swine. Can.J.comp.Med. 1975, 39, 7-16.

Done SH, Meredith MJ, Ashdown RR: Detachment of the ischial tuberosity in sows. Vet.Rec. 1979, 105, 520-523.

Erdal DE, Grøndalen T: Klaulidelser hos gris, registrert og bedømt etter slakting; en preliminær rapport. (Claw lesions in pigs, registrated and evaluated after slaughter, a preliminary report). Proceedings of NJF-seminar no. 111 Förbättringar av husdjurens benhälsa. Sånga-Säby, Sweden, 7.-8. October $1986.4 \mathrm{pp}$.

Fritschen RD, Hogg A, Cunningham PJ: The effect of material and management on claw characteristics and lameness of growing-finishing swine. Proc. $4^{\text {th }}$ Int. Pig Veterinary Society Congress, Ames., C9.

Gjein $H$, Larssen RB: Housing of pregnant sows in loose and confined systems - a field study. 2. Claw lesions: Morphology, prevalence, location and relation to age. Acta vet.scand. 1995, 36, 433-442.

Goedegebuure SA, Rothschild MF, Christian LL, Ross $R F$ : Severity of osteochondrosis in three genetic lines of Duroc swine divergently selected for front leg-weakness. Livest.Prod.Sci. 1988, 19, 487-498.

Grøndalen T: Osteochondrosis and arthrosis in pigs. I. Incidence in animals up to $120 \mathrm{~kg}$ liveweight. Acta vet.scand. 1974a, 15, 1-25.

Grøndalen T: Osteochondrosis and arthrosis in pigs. II. Incidence in breeding animals. Acta vet.scand. 1974b, 15, 26-42.

Grøndalen T: Leg weakness in pigs. I. Incidence and relationship to skeletal lesions, feeding level, protein and mineral supply, exercise and exterior conformation. Acta vet.scand. 1974c, 15, 555573.

Hill MA: Causes of degenerative joint disease (osteoarthrosis) and dyschondroplasia (osteochondrosis) in pigs. J.Am.Vet.Med.Assoc. 1990, 197, 107-113.

Hill MA: Locomotory disorders of swine. Proc. $15^{\text {th }}$ Int. Pig Veterinary Society Congress, Birmingham, England. 5-9 July 1998, 181-194.

Häni $H$, Troxler J, Würsten B: Untersuchungen zum Einfluss der Haltung auf Verbreitung und Schweregrad von Osteochondrosis (OC) bei Mastschweinen: Vergleich der Haltung im Offen- 
front-Tiefstreustall (OF) und auf Teilspaltenboden (TS). (Investigation of the influence of housing on incidence and severity of osteochadrosis (OC) in fattening pigs: A comparison between open front stable with deep straw bedding (OF) and closed stable with partly slatted floor (TS). Schweiz.Arch.Tierheilk. 1983, 125, 453-475.

Jubb KVF, Kennedy PC, Palmer N: Pathology of domestic animals., 3th ed. Academic Press Inc., San Diego 1985.

Jubb KVF, Kennedy PC, Palmer N: Pathology of domestic animals., 4th ed. Academic Press Inc., San Diego 1993.

Jørgensen B: Effect of different energy and protein levels on leg weakness and osteochondrosis in pigs. Livest.Prod.Sci. 1995, 41, 171-181.

Jørgensen $B$ : Longevity of breeding sows in relation to leg weakness symptoms at six months of age. Acta vet.scand. 2000, 41, 105-121.

Jørgensen B, Arnbjerg J, Aaslyng M: Pathological and radiological investigations on osteochondrosis in pigs, associated with leg weakness. J.Vet. Med.A 1995, 42, 489-504.

Kornegay ET, Bryant KL, Notter DR: Toe lesion development in gilts and sows housed in confinement as influenced by toe size and toe location. Applied Agricultural Research 1990, 3, 328-334.

Mouttotou N, Hatchell FM, Lundervold M, Green $L E$ : Prevalence and distribution of foot lesions in finishing pigs in south-west England. Vet.Rec. 1997, 141, 115-120.

Nakano T, Aherne FX: Articular cartilage lesions in female breeding swine. Can.J.Anim.Sci. 1993, 73, 1005-1008.

Nakano T, Aherne FX, Thompson JR: Leg weakness and osteochondrosis in pigs. Pig News and Information 1981, 2, 29-34.

Nakano T, Brennan JJ, Aherne FX: Leg weakness and osteochondrosis in swine: $\mathrm{A}$ review. Can.J.Anim.Sci. 1987, 67, 883-901.

Nielsen NC: Arthrosis in pigs. Nord.Vet.-Med. 1973, 25, 17-27.

Olsson S-E, Reiland S: The nature of osteochondrosis in animals. Summary and conclusions with comparative aspects on osteochondritis dissecans in man. Acta Radiol.[Suppl] 1978, 358, 299-306.

Penny RHC: Locomotor dysfunction causing reproductive failure. In: Morrow DA (Ed.): Current therapy in theriogenology. W.B. Saunders, Philad. Pa., 1980, 1041-1045.

Penny RHC, Osborne AD, Wright AI: The causes and incidence of lameness in store and adult pigs. Vet.Rec. 1963, 75, 1225-1240.

Penny RHC, Osborne AD, Wright AI, Stephens TK: Foot-rot in pigs: Observations on the clinical disease. Vet.Rec. 1965, 77, 1101-1107.

Petterson K, Reiland S: Avløsning av apofysen på tuber ischii - en orsag till bakdelsførlamning ock førlossningssvårigheter hos sugga. (Avulsion of the apophysis of the ischial tuberosity in the sow as a cause of lameness in the hind legs and dystochia). Sv.Vet.Tidn. 1967, 22, 648-651.

Raundahl K: Biotin i relation til klovlidelser hos søer. (Biotin in relation to claw disorders in sows). 5 points opgave i svineproduktion B., 1992, Royal Veterinary and Agricultural University, Copenhagen.

Reiland S: Pathology of so-called leg weakness in the pig. Acta Radiol.[Suppl] 1978a, 358, 23-44.

Reiland S: Morphology of osteochondrosis and sequelae in pigs. Acta Radiol.[Suppl] 1978b, 358, 45-90.

Reiland S, Ordell-Gustafson N, Lundeheim N: Heredity of osteochondrosis. A correlative and comparative investigation in different breeds using progeny testing. Proc. $6^{\text {th }}$ Int. Pig Veterinary Society Congress, 30 June - 3 July 1980, Denmark, 328.

Sabec vD: Zur Symptomatologie und Diagnostik der Sitzbeinhöckerablösung (Apophyseolysis) beim Schwein. (Symptomatology and diagnosis of apophyseolysis in pigs). Dtsch.Tierärztl.Wschr. 1971, 78, 5-9.

SAS Institute Inc.: SAS/STAT ${ }^{\mathrm{TM}}$ User's Guide, Version 6, 4th edn. SAS Institute Inc., Cary, N.C. 1989.

SAS Institute Inc.: SAS ${ }^{\mathrm{TM}}$ Technical Report P-229, SAS/STATTM Software: Changes and Enhancements, Release 6.07, SAS Institute Inc., Cary, N.C. 1992.

Simmins PH, Brooks PH: Supplementary biotin for sows: Effect on claw integrity. Vet.Rec. 1988, 122, 431-435.

Smedegaard HH: Bensvaghed og klovpleje hos svin.

(Leg weakness and foot care in pigs). Dansk Vet.Tidsskr. 1975, 58, 890-893.

Smedegaard HH: Klovpleje hos svin. Rutinemæssig klovbeskæring bør være en del af produktionskontrollen. (Foot care. Rutine claw trimming ought to be part of the production control). Hyologisk Tidsskrift Svinet 1987, 8, 28-32.

Stein TE, Dijkhuizen A, D'Allaire S, Morris RS: Sow culling and mortality in commercial swine breed- 
ing herds. Prev.Vet.Med. 1990, 9, 85-94.

Van Alstine WG, Toben CG: Detachment of the tuber ischiadicum in swine. Cont.Educ. 1989, 11, 874879.

Verdijk ATM: Bewegingsstoonissen en beebzwakte bij varkens. (Locomotion disorders and legweakness in pigs). Tijdschr. Diergeneesk. 1969, 94, 1649-1666.

Von Knezevic P: Klauenpflege beim Schwein. (Foot care in pigs). Dtsch.Tierärztl.Wschr. 1962, 69, 364-366.

Webb NG: Compressive stresses on, and the strength of, the inner and outer digits of pigs' feet, and the implications for injuri and floor design. J.Agric.Engng Res. 1984, 30, 71-80.

Webb NG, Penny RHC, Johnston AM: Effect of a dietary supplement of biotin on pig hoof horn strength and hardness. Vet.Rec. 1984, 114, 189

\author{
Sammendrag \\ Osteochondrose/ osteoartrose og klovlidelser $i$ søer, \\ sammenhaeng med bensvaghed.
}

Formålet med undersøgelsen var at undersøge sammenhængen mellem forskellige bensvaghedssymptomer og osteochondrose/osteoartrose og klovlidelser i søer tillige med indflydelsen af alder på disse egenskaber. 117 søer fulgtes fra 6 måneders alderen indtil udsættelse og bedømtes for bensvaghedssymptomer én gang $i$ hver drægtighed på en skala fra 1 (normal) til 4 (svære forandringer). Ved slagtning blev forandringer i led, vækstzoner og klove registreret på en skala fra 1 (normal) til 5 (meget svære forandringer). Osteartrotiske forandringer var stærkt associeret med osteochondrotiske forandringer i humerus og femur kondyler. De kliniske symptomer for osteochondrose og osteoartrose fandtes at være: krumme forben, udaddrejede ben, stejle koder på bagben, stive bevægelser, halthed og udskridningstendens (kun for læsioner i tuber ischii vækstzonen). De kliniske symptomer for klovlidelser var: krumme forben, stejle koder og haser, udaddrejede bagben, understillede bagben, stive bevægelser, svingende bagpart, paradeskridt, udskridningstendens og halthed. Forvoksede klove var stærkt associeret med bensvaghed, hvilket taler for at anvende klovbeskæring i sopopulationen.

(Received July 26, 1999; accepted January 7, 2000).

Reprints may be obtained from: B. Jørgensen, Danish Institute of Agricultural Sciences, Research Centre Foulum, P.O. Box 50, DK-8830 Tjele, Denmark. E-mail: bente.jorgensen@agrsci.dk, tel: +45 899913 18, fax: +4589991500 . 